\title{
Overweight and abdominal obesity in adults living with HIV/AIDS
}

\author{
Aline de Cássia Oliveira Castro ${ }^{1 *}$, Erika Aparecida Silveira ${ }^{2 *}$, Marianne de Oliveira Falco $^{3}$, Max Weyler Nery $^{4}$, \\ Marília Dalva Turchi ${ }^{5}$ \\ ${ }^{1}$ MSc - Professor of Nutrition, Pontifícia Universidade Católica de Goiás (PUC Goiás). Nutritionist, Secretaria Municipal de Saúde de Goiânia, Goiânia, GO, Brazil \\ ${ }^{2} \mathrm{PhD}$ - Associate Professor, Posgraduation Program Health Science, Universidade Federal de Goiás (UFG), Goiânia, GO, Brazil \\ ${ }^{3} \mathrm{MSc}$ - Nutritionist, Hospital de Urgência Governador Otávio Lage, Goiânia, GO, Brazil \\ ${ }^{4} \mathrm{PhD}$ - Cardiologist. Professor of Medicine, PUC Goiás, Goiânia, GO, Brazil \\ ${ }^{5}$ PhD - Associate Professor, Instituto de Patologia Tropical e Saúde Pública, UFG, Goiânia, GO, Brazil
}

\section{SUMMARY}

Study conducted at Universidade Federal de Goiás (UFG), Goiânia, GO, Brazil

Article received: $1 / 22 / 2015$ Accepted for publication: 8/30/2015 ${ }^{\star}$ Correspondence: Pontifícia Universidade Católica de Goiás Departamento de Enfermagem, Fisioterapia e Nutrição, Área IV Address: $1^{\text {a }}$ Avenida, esquina com avenida Universitária, Setor Universitário Goiânia, GO - Brazil Postal code: $74605-020$ Tel.: +55 $628512-0910$ alinecocastro@gmail.com erikasil@terra.com.b

http://dx.doi.org/10.1590/1806-9282.62.04.353

Financial support: Funding by the CNPq Process 478741/2008-1/FAPEG Process 02/2009

\section{INTRODUCTION}

Highly active antiretroviral therapy (HAART), advocated since 1996, has reduced the mortality and morbidity of HIV infection, changing the profile of HIV/AIDS progression. ${ }^{1}$ In Brazil, universal and free access to this therapy has resulted in relevant improvements in survival and quality of life for people living with HIV/AIDS (PLWHA) with a significant reduction in episodes of opportunistic diseases. ${ }^{2}$ In this scenario, HIV infection has become treated chronically and other health problems caused by the increased survival of patients and prolonged use of HAART have emerged. Thus, anthropometric and metabolic changes have been a cause for concern, contributing to a higher risk of cardiovascular disease and increasing the challenge of treating this infection due to the chronic complications. ${ }^{3,4}$
\end{abstract}

Objective: To investigate the prevalence of overweight, abdominal obesity and associated factors in people living with HIV/AIDS (PLWHA).

Method: Cross-sectional study with 270 PLWHA. A questionnaire was applied to investigate sociodemographic, clinical and lifestyle characteristics. Weight, height and waist circumference were measured. BMI $\geq 25 \mathrm{~kg} / \mathrm{m}^{2}$ was considered overweight, while abdominal obesity referred to waist circumference $\geq 102 \mathrm{~cm}$ for men and $\geq 88 \mathrm{~cm}$ for women. The authors used multiple Poisson regression with 5\% significance level.

Results: The prevalence of overweight and abdominal obesity was $33.7 \%$ and $12.6 \%$, respectively, referring to $37.9 \%$ of women and $5.7 \%$ of men ( $\mathrm{p}<0.001$ ). Overweight was associated with age of $40-49$ years and $\geq 50$ years, non-use of ARV therapy, and lower tertile of consumption of risk foods. Abdominal obesity was associated with: female gender, age of $40-49$ years and $\geq 50$ years, income greater than four times the minimum wage, and CD4+ lymphocyte count $>350$ cells $/ \mathrm{mm}^{3}$. Conclusion: There was a high prevalence of overweight and abdominal obesity associated with sociodemographic and clinical conditions, and consumption of risk foods. This scenario indicates the need for reorientation of the health care focus in this population.

Keywords: HIV, acquired immunodeficiency syndrome, overweight, obesity, abdominal obesity, assessment of nutritional status.
Given this new reality, different changes to patterns of nutritional status have appeared and long-term complications related to overweight, obesity and redistribution of body fat have gained importance. ${ }^{5}$ Studies on the nutritional profile of PLWHA have shown a prevalence of excess weight over $30 \%,{ }^{6-8}$ and abdominal obesity has also been observed in this population. ${ }^{7,9}$ However, studies on the prevalence of overweight and abdominal obesity in conjunction with the evaluation of associated factors are still scarce, limiting the planning of surveillance, treatment and control.

Within this context, the objective of this study was to investigate the prevalence of overweight and abdominal obesity and factors associated with these conditions in PLWHA. 


\section{Method}

This was a cross-sectional study within a cohort entitled: Predictors of cardiovascular disease in PLWHA - PRECOR. The cohort was developed with patients cared for at the Outpatient Clinic of Infectious and Parasitic Diseases (ADIP) at the Hospital das Clínicas (HC) of the Universidade Federal de Goiás (UFG), Goiânia. This is a reference outpatient clinic in the treatment of HIV/AIDS in the State of Goiás.

The research project was approved by the Ethics Committee of the HC/UFG, CEPMHA/HC/UFG under protocol $n^{\circ} 163 / 09$. Patients who agree to participate in study signed an informed consent form (ICF).

The population of the study consisted of 152 PLWHA. The inclusion criteria were: being 19 years of age or older, being a patient at the ADIP/HC/UFG diagnosed with HIV/AIDS and attending consultations at this clinic in the period from October to July 2011. We excluded pregnant women and patients with opportunistic disease diagnosed less than two months before, or earlier than this but without clinical resolution during this period.

The study procedures were conducted by interviewers and anthropometrists previously trained and standardized as part of a pilot study. For anthropometric standardization, we used the method of technical error of measurement $t^{10}$ to provide greater measurement accuracy and precision. All of the equipment used was constantly calibrated.

The anthropometric measurements included weight, height and waist circumference (WC). Weight was measured using Tanita Ironman Segmental Body Composition Monitor BC 558 digital scales with capacity for 150 $\mathrm{kg}$. Height was measured using inextensible measuring tape with a length of 2 meters and precision of 0.1 centimeter, attached to a smooth wall without baseboard, with the help of a plumb line and set-square. WC was measured in centimeters using a millimetric, inextensible measuring tape with 0.1 centimeter precision. Weight, height and WC were measured twice using the arithmetic mean of these measurements as a result.

Based on weight and height, we calculated the body mass index (BMI) by dividing the weight ( $\mathrm{kg}$ ) by the square of height $(\mathrm{m})$. Overweight was considered as a BMI $\geq 25$ $\mathrm{kg} / \mathrm{m}^{2}$, while BMI $\geq 30 \mathrm{~kg} / \mathrm{m}^{2}$ was set as obesity. ${ }^{11}$

WC was used for diagnosis of abdominal obesity. Abdominal obesity was considered using the cut-off points for increased risk of metabolic complications (WC $\geq 102$ $\mathrm{cm}$ in men and $\geq 88 \mathrm{~cm}$ in women). ${ }^{12}$

All participants responded to a structured questionnaire containing socio-demographic (gender, age, educa- tion, personal income and marital status), clinical [time of diagnosis, use of HAART, time of use of HAART, use of Protease inhibitors (PI), CD4+ T lymphocyte count] and lifestyle (smoking, alcohol consumption, physical activity levels and food consumption score for risk of cardiovascular disease) information.

The participants were surveyed about the time of HIV diagnosis and use of HAART. The time of use of HAART and CD4+ T lymphocyte count were obtained from a review of medical records. For the CD4+ T lymphocyte count we considered the results closest to the time of collection of the data. History of antiretroviral drug use was taken from pharmaceutical records at the healthcare unit. For this analysis, we considered the drugs prescribed at the time of collection of data. The outpatient clinic is a routine research location and all of this information is recorded accurately by trained staff.

Smokers were considered as those who claimed to be a smoker at the time of data collection, regardless of the time and the amount of cigarettes. Consumption of alcohol was considered as consumption regardless of the type, frequency and dosage.

To analyze physical activity we applied the International Physical Activity Questionnaire (IPAQ), an instrument proposed by the International Consensus Group on Physical Activity Measurements. ${ }^{13}$ Considering the frequency, intensity and duration criteria, the levels of physical activity were classified into three categories: low, moderate and high. ${ }^{14}$

For analysis of protective food consumption and the risk of cardiovascular disease we applied the food frequency questionnaire (FFQ) adapted from the Fornés instruments. ${ }^{15}$ The risk foods were: milk, cheese, yogurt, cream cheese, meat, poultry, egg, sausages, meats preserved in salt, viscera, bacon, back fat, lard, mayonnaise, butter, margarine, candy, ice cream, artificial juice and soft drinks. The protective foods were: rice, pasta, tubers, oat bran, wheat bran, beans, soybeans, type $A$ vegetables, type $B$ vegetables, fruit and fruit juice. Using these foods we calculated risk and protection scores for cardiovascular diseases. In the calculation of the score a value was assigned to each food according to the frequency of consumption, followed by calculation of the scores using the total of the values of each food divided by the total number of risk or protection foods. ${ }^{16}$

The database was structured using EPIDATA $₫$ software version 3.0, with double-entry for evaluation of the consistency and correctness of data. Strata software version 8.0 was used for data analysis.

The prevalence of overweight and abdominal obesity outcomes and their respective $95 \%$ confidence inter- 
vals were calculated. Student's t-test was used to compare average consumption of risk and protection foods. Then, bivariate analysis was performed to verify the association between independent variables and outcomes by applying Pearson's chi-squared test or Fisher's exact test. For both outcomes a non-exposed category was defined for calculating the ratio of prevalence, the best case scenario, that is, the category with the lowest prevalence for each variable studied.

All variables with a p-value less than 0.20 in the bivariate analysis were included in the multivariate analysis. Poisson multiple regression was carried out according to the hierarchical theoretical model, structured into three blocks of variables: (i) socio-demographic, (ii) clinical and (iii) lifestyle.

Using a model that included all the variables from the same level, the variables with a p-value greater than 0.05 were removed one by one, using the maximum likelihood ratio test. The prevalence ratio and the p-value presented are adjusted using the variables from the same level or higher.

\section{Results}

In the 270 individuals assessed, the prevalence of overweight was $33.7 \%$ (95\% CI 28.2;39.7) and obesity was $4.8 \%$ (95\% CI 2.7;8.3). The prevalence of abdominal obesity was $12.6 \%$ (95\% CI 9.0;17.3).

In relation to the characteristics of PLWHA who participated in the research, $78.5 \%$ were male, $60.7 \%$ were aged between 19 and 39 years, $23 \%$ were smokers, $50 \%$ consumed alcoholic beverages and $60 \%$ had a low level of physical activity. The average time of diagnosis of HIV infection was $2.6(\mathrm{SD}=2.8)$ years. The $\mathrm{CD} 4+\mathrm{T}$ lymphocyte count was greater than 350 cells $/ \mathrm{mm}^{3}$ in $73.6 \%$ of the individuals and the use of HAART was reported by $68.5 \%$ of the participants, with the average time using this therapy at 2.3 $(\mathrm{SD}=2.5)$ years. In relation to the classes of drugs used, $23.8 \%$ of those treated with HAART were taking at least one class of drug, regardless of the combinations (Table 1).

For risk food consumption, the average of the scores was $8.7(\mathrm{SD}=3.2)$, while the average of the scores of protective food consumption was $13.5(\mathrm{SD}=3.8)$, significantly higher than the first $(\mathrm{p}<0.001)$ (Table 1).

For both outcomes analyzed an association was noted with: the female gender, age $\geq 40$ years, lower levels of formal education ( $\leq 8$ years), marital status as widower, legally separated or separated, and lower tertile of the risk food consumption score. We noted that the higher the age, the higher the prevalence of overweight and abdominal obesity, while the opposite was found for the risk food consumption score. Only for the overweight outcome no association was found regarding use of HAART. For abdominal obesity we noted an association with personal income higher than four minimum wages (Table 1).

After multivariate analysis, for the overweight outcome, an association was noted with: age between 40 and 49 years (PR: 1.16) and $\geq 50$ years (PR: 1.20 ), non-use of HAART (PR: 1.15) and lower tertile of risk foods consumption (PR: 1.15) (Table 2).

For the abdominal obesity outcome we observed an association with: female gender (PR: 4.91), age between 40 and 49 years (PR: 4.88 ) and $\geq 50$ years (PR: 4.99), personal income higher than four minimum wages (PR: 2.87) and CD4+ T lymphocytes count $>350$ cells $/ \mathrm{mm}^{3}$ (PR: 2.45 ) (Table 3 ).

\section{Discussion}

This research contributes to the diagnosis of the prevalence of overweight and abdominal obesity in PLWHA in outpatient treatment at a reference hospital in the Midwest of Brazil and the study of associated factors, also regarding food consumption, which is still poorly investigated.

The high prevalence of overweight found in this study is consistent with the prevalence observed in other national and international studies involving PLWHA. $6,8,17,18$ With the use of new antiretroviral drug therapies and the consequent increase in survival of patients, low body weight is no longer frequent, giving way to overweight and obesity. ${ }^{7,8,19}$ Thus, the current prevalence of overweight in PLWHA reflects the current trends of the general population, affecting around $49.0 \%$ of Brazilian adults. ${ }^{20}$ It is worth noting that the patients studied were mostly treated with HAART and had counts of CD4+ T lymphocytes $>350$ cells $/ \mathrm{mm}^{3}$, which may have favored the higher prevalence of overweight. Although the pathophysiological mechanisms and the complications of obesity in PLWHA are not completely elucidated, it is known that this condition can have important functional implications in the disease, ${ }^{21}$ in addition to increasing the risk of developing cardiovascular problems.

Abdominal obesity also showed a high prevalence, at $12.6 \%$, corroborating studies conducted with patients on HAART. ${ }^{7,22,23}$ A study that evaluated patients treated with HAART or otherwise found a prevalence of abdominal obesity of $17.0 \%{ }^{24}$ This type of obesity, characterized by the accumulation of fat in the abdominal region, is recognized as a risk factor for cardiovascular disease, diabetes, dyslipidemia and metabolic syndrome, ${ }^{25}$ and monitoring the metabolic profile of patients with abdominal obesity is important to control cardiometabolic risks and prevent other diseases. 
TABLE 1 Characteristics of people living with HIV/AIDS, prevalence of overweight and abdominal obesity, and association analysis according to sociodemographic, clinical and lifestyle variables. Goiânia, Goiás, Brazil, 2010-2011 (N=270).

\section{Variables}

Patient Overweight characteristics Prevalence PR (95CI) N (\%) N (\%)

\begin{tabular}{|c|c|c|c|c|c|c|c|}
\hline \multirow[b]{2}{*}{ Gender } & \multirow[t]{2}{*}{$\mathbf{N}(\%)$} & \multicolumn{2}{|l|}{ N (\%) } & \multicolumn{3}{|c|}{ N (\%) } & \multirow[b]{2}{*}{$<0.001$} \\
\hline & & & & 0.008 & & & \\
\hline Male & $212(78.5)$ & $63(29.7)$ & 1 & & $12(5.7)$ & 1 & \\
\hline Female & $58(21.5)$ & $28(48.3)$ & $1.14(1.04-1.26)$ & & $22(37.9)$ & $6.70(3.53-12.73)$ & \\
\hline Age (years) & & & & $<0.001$ & & & 0.001 \\
\hline 19 to 39 & $164(60.7)$ & $40(24.4)$ & 1 & & $6(3.7)$ & 1 & \\
\hline 40 to 49 & $72(26.7)$ & $33(45.8)$ & $1.17(1.06-1.29)$ & & $17(23.6)$ & $6.45(2.65-15.72)$ & \\
\hline$\geq 50$ & $34(12.6)$ & $18(52.9)$ & $1.23(1.09-1.39)$ & & $11(32.4)$ & $8.84(3.50-22.31)$ & \\
\hline Education (years) ${ }^{* * *}$ & & & & 0.031 & & & 0.033 \\
\hline$\leq 4$ & $37(13.7)$ & $16(43.2)$ & $1.18(1.03-1.35)$ & & $7(18.9)$ & $2.13(0.94-4.81)$ & \\
\hline 5 to 8 & $53(19.6)$ & $23(43.4)$ & $1.18(1.05-1.33)$ & & $11(20.8)$ & $2.34(1.15-4.73)$ & \\
\hline 9 to 11 & $105(38.9)$ & $36(34.3)$ & $1.11(0.99-1.23)$ & & $16(8.9)$ & 1 & \\
\hline$\geq 12$ & $75(27.8)$ & $16(21.3)$ & 1 & & - & - & \\
\hline $\begin{array}{l}\text { Income } \\
\text { (minimum wages) }\end{array}$ & & & & 0.809 & & & $0.013^{* *}$ \\
\hline$\leq 1$ & $90(33.3)$ & $28(31.1)$ & 1 & & $15(16.7)$ & $1.94(0.98-3.84)$ & \\
\hline 2 to 4 & $163(60.4)$ & $57(35.0)$ & $1.03(0.94-1.13)$ & & $14(8.6)$ & 1 & \\
\hline$>4$ & $16(5.9)$ & $5(31.3)$ & $1.00(0.83-1.21)$ & & $5(31.3)$ & $3.64(1.50-8.81)$ & \\
\hline Marital status & & & & $<0.001$ & & & $<0.001$ \\
\hline Single & $160(59.3)$ & $41(25.6)$ & 1 & & $10(6.3)$ & 1 & \\
\hline Married or common-law & $66(24.4)$ & $25(37.9)$ & $1.10(0.99-1.21)$ & & $10(15.2)$ & $2.42(1.06-5.56)$ & \\
\hline $\begin{array}{l}\text { Widow(er), divorced, } \\
\text { separated }\end{array}$ & $44(16.3)$ & $25(56.8)$ & $1.25(1.12-1.39)$ & & $14(31.8)$ & $5.09(2.43-10.68)$ & \\
\hline $\begin{array}{l}\text { Time of diagnosis } \\
\text { (years) }\end{array}$ & & & & 0.438 & & & 0.061 \\
\hline$<1$ & $71(28.06)$ & $22(30.99)$ & 1 & & $6(8.4)$ & 1 & \\
\hline 1 to 3 & $94(37.15)$ & $37(39.36)$ & $1.06(0.95-1.19)$ & & $10(10.6)$ & $1.26(0.48-3.31)$ & \\
\hline$>3$ & $88(34.78)$ & $28(31.82)$ & $1.01(0.90-1.12)$ & & $16(18.2)$ & $2.15(0.89-5.22)$ & \\
\hline Use of HAART & & & & 0.042 & & & 0.609 \\
\hline No & $85(31.5)$ & $36(42.4)$ & $1.10(1.00-1.20)$ & & $12(14.1)$ & $1.19(0.62-2.29)$ & \\
\hline Yes & $185(68.5)$ & $55(29.7)$ & 1 & & $22(11.9)$ & 1 & \\
\hline Time of HAART (years)** & & & & 0.980 & & & $0.221 * *$ \\
\hline$<1$ & $62(35.23)$ & $19(30.65)$ & $1.01(0.89-1.14)$ & & $4(6.4)$ & 1 & \\
\hline 1 to 3 & $57(32.39)$ & $18(31.58)$ & $1.01(0.89-1.15)$ & & $8(14.0)$ & $2.18(0.69-6.86)$ & \\
\hline$>3$ & $57(32.39)$ & $17(29.82)$ & 1 & & $9(15.8)$ & $2.45(0.80-7.54)$ & \\
\hline Use of $\mathrm{Pl}^{* *}$ & & & & 0.791 & & & 0.717 \\
\hline No & $138(76.2)$ & $41(29.7)$ & 1 & & $16(11.6)$ & 1 & \\
\hline Yes & $44(23.8)$ & $14(31.8)$ & $1.02(0.90-1.15)$ & & $6(13.6)$ & $1.18(0.49-2.83)$ & \\
\hline CD4+ count (cells $\left./ \mathrm{mm}^{3}\right)^{* *}$ & & & & 0.454 & & & $0.096 * *$ \\
\hline$\leq 350$ & $69(26.44)$ & $21(30.43)$ & 1 & & $5(7.2)$ & 1 & \\
\hline$>350$ & $192(73.6)$ & $68(35.42)$ & $1.04(0.94-1.14)$ & & $29(15.1)$ & $2.08(0.84-5.18)$ & \\
\hline
\end{tabular}

Abdominal obesity

p-value* Prevalence PR $(95 \mathrm{CI})$

p-value*

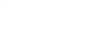


TABLE 1 (Cont.) Characteristics of people living with HIV/AIDS, prevalence of overweight and abdominal obesity, and association analysis according to sociodemographic, clinical and lifestyle variables. Goiânia, Goiás, Brazil, 2010-2011 $(\mathrm{N}=270)$.

\begin{tabular}{|c|c|c|c|c|c|c|c|}
\hline \multirow[t]{2}{*}{ Variables } & \multirow{2}{*}{$\begin{array}{l}\text { Patient } \\
\text { characteristics } \\
\mathrm{N}(\%)\end{array}$} & \multicolumn{3}{|l|}{ Overweight } & \multicolumn{3}{|c|}{ Abdominal obesity } \\
\hline & & $\begin{array}{l}\text { Prevalence } \\
\text { N (\%) }\end{array}$ & PR $(95 \mathrm{Cl})$ & p-value* & $\begin{array}{l}\text { Prevalence } \\
\text { N (\%) }\end{array}$ & PR (95Cl) & p-value* \\
\hline Smoker & & & & 0.975 & & & 0.725 \\
\hline No & $208(77.0)$ & $70(33.7)$ & 1 & & $27(13.0)$ & $1.15(0.53-2.52)$ & \\
\hline Yes & $62(23.0)$ & $21(33.9)$ & $1.00(0.91-1.11)$ & & $7(11.3)$ & 1 & \\
\hline Alcohol consumption & & & & 0.520 & & & 0.271 \\
\hline No & $135(50.0)$ & $43(31.9)$ & 1 & & $20(14.8)$ & $1.43(0.75-2.71)$ & \\
\hline Yes & $135(50.0)$ & $48(35.6)$ & $1.03(0.94-1.12)$ & & $14(10.4)$ & 1 & \\
\hline Physical activity & & & & 0.985 & & & $0.867 * *$ \\
\hline Low & $162(60.0)$ & $55(34.0)$ & $1.01(0.91-1.11)$ & & $20(12.3)$ & $1.17(0.42-3.24)$ & \\
\hline Moderate & $70(25.9)$ & $23(32.9)$ & 1 & & $10(14.3)$ & $1.36(0.46-4.05)$ & \\
\hline High & $38(14.1)$ & $13(34.2)$ & $1.01(0.88-1.16)$ & & $4(10.5)$ & 1 & \\
\hline $\begin{array}{l}\text { Consumption of risk } \\
\text { foods (score) }\end{array}$ & & & & $<0.001$ & & & $0.001 * *$ \\
\hline $1^{\text {st }}$ tertile $(1.42 \vdash 6.92)$ & $88(34.24)$ & $44(50.00)$ & $1.21(1.09-1.34)$ & & $19(21.6)$ & $4.53(1.61-12.80)$ & \\
\hline $2^{\text {nd }}$ tertile $(6.92 \vdash 10.00)$ & $85(33.07)$ & $25(29.41)$ & $1.04(0.94-1.16)$ & & $10(11.8)$ & $2.47(0.80-7.59)$ & \\
\hline $3^{\text {rd }}$ tertile $(10.00 \vdash 19.33)$ & $84(32.68)$ & $20(23.81)$ & 1 & & $4(4.8)$ & 1 & \\
\hline
\end{tabular}

*Wald test; **Fisher's exact test; ${ }^{* *}$ Education categories for abdominal obesity: $=4$ years, 5-8 years, 9 years; PR (95CI): prevalence ratio and $95 \%$ confidence interval; HAART: highly active antiretroviral therapy; PI: protease inhibitor.

TABLE 2 Factors associated with overweight in crude and adjusted analysis using hierarchical poisson multiple regression in people living with HIV/AIDS. Goiânia, Goiás, Brazil, 2010-2011 (N=270).

\begin{tabular}{|c|c|c|c|c|}
\hline Variables & Crude PR (95CI) & p-value* & Adjusted PR (95CI) & p-value* \\
\hline \multicolumn{5}{|l|}{$1^{\text {st }}$ level } \\
\hline Age (years) & & $<0.001$ & & 0.001 \\
\hline 19 to 39 & 1 & & 1 & \\
\hline 40 to 49 & $1.17(1.06-1.29)$ & & $1.16(1.05-1.28)$ & \\
\hline$\geq 50$ & $1.23(1.09-1.39)$ & & $1.20(1.06-1.36)$ & \\
\hline \multicolumn{5}{|l|}{$2^{\text {nd }}$ level } \\
\hline Use of HAART & & 0.042 & & 0.002 \\
\hline No & $1.10(1.00-1.20)$ & & $1.15(1.05-1.25)$ & \\
\hline Yes & 1 & & 1 & \\
\hline \multicolumn{5}{|l|}{$3^{\text {rd }}$ level } \\
\hline Consumption of risk foods (score) & & $<0.001$ & & $<0.001$ \\
\hline $1^{\text {st }}$ tertile $(1.42 \vdash 6.92)$ & $1.21(1.09-1.34)$ & & $1.15(1.04-1.28)$ & \\
\hline $2^{\text {nd }}$ tertile $(6.92 \vdash 10.00)$ & $1.04(0.94-1.16)$ & & $1.02(0.92-1.13)$ & \\
\hline $3^{\text {rd }}$ tertile $(10.00 \vdash 19.33)$ & 1 & & 1 & \\
\hline
\end{tabular}

*Wald test; PR (95CI): prevalence ratio and 95\% confidence interval; HAART: highly active antiretroviral therapy. 
TABLE 3 Factors associated with obesity in crude and adjusted analysis using hierarchical poisson multiple regression in people living with HIV/AIDS. Goiânia, Goiás, Brazil, 2010-2011 (N=270).

\begin{tabular}{|c|c|c|c|c|}
\hline Variables & Crude PR (95CI) & p-value* & Adjusted PR (95CI) & p-value* \\
\hline \multicolumn{5}{|l|}{$1^{\text {st }}$ level } \\
\hline Gender & & $<0.001$ & & $<0.001$ \\
\hline Male & 1 & & 1 & \\
\hline Female & $6.70(3.53-12.73)$ & & $4.91(2.49-9.70)$ & \\
\hline Age (years) & & 0.001 & & $<0.001$ \\
\hline 19 to 39 & 1 & & 1 & \\
\hline 40 to 49 & $6.45(2.65-15.72)$ & & $4.88(1.99-11.98)$ & \\
\hline$\geq 50$ & $8.84(3.50-22.31)$ & & $4.99(1.87-13.29)$ & \\
\hline Income (minimum wages) & & $0.013 * *$ & & 0.016 \\
\hline$\leq 1$ & $1.94(0.98-3.84)$ & & $1.05(0.56-1.94)$ & \\
\hline 2 to 4 & 1 & & 1 & \\
\hline$>4$ & $3.64(1.50-8.81)$ & & $2.87(1.35-6.11)$ & \\
\hline \multicolumn{5}{|l|}{$2^{\text {nd }}$ level } \\
\hline CD4+ count (cells $/ \mathrm{mm}^{3}$ ) & & $0.096 * *$ & & 0.021 \\
\hline$\leq 350$ & 1 & & 1 & \\
\hline$>350$ & $2.08(0.84-5.18)$ & & $2.45(1.13-5.35)$ & \\
\hline
\end{tabular}

*Wald test; **Fisher's exact test; PR (95Cl): prevalence ratio and $95 \%$ confidence interval.

In this study the association between abdominal obesity and the female gender was maintained after multivariate analysis, which is in accordance with the research literature on PLWHA. ${ }^{7,9,23}$ As for overweight, there was no association with females, unlike another two studies on PLWHA. ${ }^{6,26}$ In the Brazilian population, however, the prevalence of overweight is very similar among both men and women. ${ }^{20}$

The prevalence of overweight and abdominal obesity increases with age. This association is troubling, because PLWHA at more advanced ages are prone to developing chronic diseases, similar to the general population at the same age range. ${ }^{22}$ The association between abdominal obesity and advanced age has been found in other studies with PLWHA. $8,9,23,26$ The highest frequency of overweight in categories of more advanced ages was also found in the Brazilian population. ${ }^{20}$

In this study, abdominal obesity was associated with higher income. The only study found that evaluated this variable in PLWHA found no such association. ${ }^{23}$ For the overweight outcome, the association with income was not observed as in other studies with PLWHA. ${ }^{6,8} \mathrm{~A}$ study conducted in Teresina, State of Piauí, including the general population showed an increased prevalence of overweight and obesity with increased income for men only. ${ }^{27}$ Studies investigating the association of these outcomes with the income variable must be conducted to broaden the discussion of this result.
The variables of level of education and marital status were not associated with any of the outcomes. Similarly, other studies found no such association in relation to level of education. ${ }^{6,8}$ In relation to the marital status variable, we found no studies that included PLWHA. Studies in the general population have shown an increased risk of overweight and abdominal obesity in individuals who are married or in a stable relationship. ${ }^{27,28}$

We noted an association between overweight and nonuse of HAART, similar to another study conducted with PLWHA. ${ }^{8}$ However, this association was not found by other researchers. ${ }^{5,6,18}$ In the studies available so far, as well as in this study, no association was found between overweight, abdominal obesity and use of regimens containing PI. $5,6,18,29$ An association with HAART, including specific regimes, is recognized with respect to lipodystrophy ${ }^{30}$ but it is not described in the literature related to excess weight.

In this study, no association was found between a higher CD4+ T lymphocyte count and overweight, corroborating a Brazilian study ${ }^{7}$ and disagreeing with others that found this association. ${ }^{6,17}$ One study showed a greater increase of CD4+ Tlymphocytes in 12 months in patients with overweight at the beginning of treatment, suggesting that this BMI range is optimal for immune reconstitution in PLWHA. ${ }^{31}$ Another study has shown that HIV-infected individuals who were obese at the time of diagnosis had higher increases in CD4+ $\mathrm{T}$ count over time compared to individuals who were overweight upon 
diagnosis. ${ }^{32}$ On the other hand, there has been some evidence that obesity has a negative effect on CD4+ T lymphocytes by decreasing these cells in PLWHA. ${ }^{33}$ Further studies are needed to elucidate this issue.

For abdominal obesity, an association was found with a CD4+ T lymphocyte count $>350$ cells $/ \mathrm{mm}^{3}$, corroborating another study. ${ }^{26}$ However, other researchers did not observe this association. ${ }^{7,23}$ The result found reaffirms the hypothesis that being overweight is linked to a better immune status, but since the studies are controversial, investigation in future research is recommended.

A significantly higher average score of consumption of protective food was noted in this research, unlike another study that found a significantly higher consumption of risk foods compared to protective foods in PLWHA. ${ }^{19}$ The lowest tertile of risk foods remained associated with overweight. We expected to find the opposite, that is, that the prevalence of overweight was greatest in the highest tertiles, since they reflect a higher consumption of high energy density foods. Studies evaluating the association between the consumption of risk foods and excess weight in PLWHA were not found. A study that evaluated the food consumption of PLWHA found lower energy consumption per kilogram of weight in higher BMI categories. ${ }^{5}$ This fact is contrary of that expected, also in this study. The authors suggested that this finding was due to underreporting of food intake by individuals with higher BMI. This hypothesis is also raised by the authors of the present study. Another study investigated the association between food consumption and abdominal obesity and showed increased risk of this type of obesity when there is lower carbohydrate intake and greater intake of lipids. ${ }^{26}$

The other lifestyle factors analyzed in this study were not associated with the outcomes. Other studies with PLWHA found smoking as a protection factor for overweight. ${ }^{6,8}$

In relation to consumption of alcoholic beverages the results of this study corroborate those of other works that failed to link it with overweight and abdominal obesity. 8,9

A high prevalence of low level of physical activity was found, as in other studies, with a prevalence of the sedentary lifestyle over $50 \% .{ }^{8,34}$ There was no association between overweight and physical activity, similar to other research. ${ }^{8}$ For the abdominal obesity outcome, this study also showed that there was no association with physical activity, unlike other research that found an association between sedentary lifestyle and abdominal obesity. ${ }^{9}$

It is known that environmental and lifestyle factors are established risk factors for the occurrence of overweight; therefore, future research to specifically investigate the association of factors related to lifestyle, food consumption and prevalence of overweight and abdominal obesity in PLWHA should be encouraged to elucidate the issues raised herein and to guide the nutritional and clinical treatment of this group of patients.

As for the limitations of this study we can cite the use of the food frequency questionnaire as a food consumption assessment method. However, although its limitations are recognized, this is a method widely used in epidemiological studies and there is no instrument for evaluation of food consumption considered as gold standard. We can also mention the transversal nature of the study as another limitation.

On the other hand, it should be noted that the sources of errors in this study were minimized by means of quality control procedures including a pilot study, training of all interviewers and anthropometrists involved, periodic calibration of the equipment, and planning and follow-up meetings with the entire team during all stages of the research.

\section{Conclusion}

In this study, we noted a concerning prevalence of overweight and abdominal obesity. A higher prevalence of overweight was found in people aged over 40 years not treated with HAART and within the lowest tertile of the risk food consumption score. Abdominal obesity was shown to be more prevalent in females aged more than 40 years, with income greater than four minimum wages, and a higher count of CD4+ $\mathrm{T}$ lymphocytes. This panorama of overweight and abdominal obesity in PLWHA signals the need for reorientation of the focus for healthcare in this population, especially with regard to nutritional care. Given these results, we emphasize the need for actions to monitor the individual's nutritional status and the development of treatment strategies that produce desirable results for preventing and controlling overweight and abdominal obesity. Public policies capable of reducing the impact of these problems and their consequences should be outlined with a focus on PLWHA.

\section{Resumo}

Excesso de peso e obesidade abdominal em adultos vivendo com HIV/aids

Objetivo: investigar em pessoas vivendo com HIV/aids (PVHA) a prevalência de excesso de peso, obesidade abdominal e fatores associados.

Método: estudo transversal com 270 PVHA. Aplicou-se questionário para investigar características sociodemográficas, clínicas e estilo de vida. Coletaram-se peso, altu- 
ra e circunferência de cintura. Consideraram-se excesso de peso o IMC $\geq 25 \mathrm{~kg} / \mathrm{m}^{2}$ e obesidade abdominal a circunferência de cintura $\geq 102 \mathrm{~cm}$ para homens e $\geq 88 \mathrm{~cm}$ para mulheres. Utilizou-se regressão de Poisson múltipla com nível de significância de 5\%.

Resultados: a prevalência de excesso de peso foi de $33,7 \%$ e de obesidade abdominal foi de $12,6 \%$, sendo $37,9 \%$ nas mulheres e 5,7\% nos homens ( $p<0,001)$. Excesso de peso foi associado com idade de 40 a 49 anos e $\geq 50$ anos, não uso de terapia antirretroviral (TARV) e menor tercil de consumo de alimentos de risco. Obesidade abdominal se associou com sexo feminino, idade de 40 a 49 anos e $\geq 50$ anos, renda própria maior que quatros salários mínimos e contagem de linfócitos T CD4+ >350 células $/ \mathrm{mm}^{3}$.

Conclusão: constatou-se elevada prevalência de excesso de peso e obesidade abdominal, associados a condições sociodemográficas, clínicas e consumo de alimentos de risco. Esse panorama sinaliza a necessidade de reorientação do foco de atenção à saúde dessa população.

Palavras-chave: HIV, síndrome da imunodeficiência adquirida, sobrepeso, obesidade, obesidade abdominal, avaliação nutricional.

\section{References}

1. Dourado I, Veras MASM, Barreira D, Brito AM. Tendências da epidemia de AIDS no Brasil após a terapia anti-retroviral. Rev Saúde Pública. 2006; 40(Suppl):9-17.

2. Hacker MA, Kaida A, Hogg RS, Bastos FI. The first ten years: achievements and challenges of the Brazilian program of universal access to HIV/AIDS comprehensive management and care, 1996-2006. Cad Saúde Pública. 2007; 23(Suppl 3):S345-59.

3. Grundy SM, Cleeman JI, Daniels SR, Donato KA, Eckel RH, Franklin BA, et al.; American Heart Association; National Heart, Lung, and Blood Institute. Diagnosis and management of the metabolic syndrome: an American Heart Association/National Heart, Lung, and Blood Institute Scientific Statement. Circulation. 2005; 112(17):2735-52.

4. Hester EK. HIV medications: an update and review of metabolic complications. Nutr Clin Pract. 2012; 27(1):51-64.

5. Hendricks KM, Willis K, Houser R, Jones CY. Obesity in HIV-infection: dietary correlates. J Am Coll Nutr. 2006; 25(4):321-31.

6. Amorosa V, Synnestyedt M, Gross R, Friedman H, MacGregror RR, Gudonis D, et al. A tale of 2 epidemics: the intersection between obesity and HIV infection in Philadelphia. JAIDS. 2005; 39(5):557-61.

7. Jaime PC, Florindo AA, Latorre MRDO, Brasil BG, Santos ECM, Segurado AAC. Prevalência de sobrepeso e obesidade abdominal em indivíduos portadores de HIV/AIDS, em uso de terapia antirretroviral de alta potência. Rev Bras Epidemiol. 2004; 7(1):65-72.

8. Mariz CA, Albuquerque MFPM, Ximenes RAA, Melo HRL, Bandeira F, Oliveira TGB, et al. Body mass index in individuals with HIV infection and factors associated with thinness and overweight/obesity. Cad. Saúde Pública. 2011; 27(10):1997-2008

9. Oliveira OMV, Medeiros RS, Nascimento MAB, Boni MS. Perfil nutricional e fatores de risco para obesidade central em pessoas que vivem com HIV/ AIDS. Comun Ciênc Saúde. 2008; 19(4):305-14.

10. Habicht JP. Estandarización de métodos epidemiológicos cuantitativos sobre el terreno. Bol Oficina Sanit Panam. 1974; 76(5):375-84.

11. World Health Organization. Defining the problem of overweight and obesity. In: Obesity: preventing and managing the global epidemic. Geneva: WHO, 2000.

12. Sociedade Brasileira de Hipertensão, Sociedade Brasileira de Cardiologia, Sociedade Brasileira de Endocrinologia e Metabologia. I Diretriz Brasileira de Diagnóstico e Tratamento da Síndrome Metabólica. Arq. Bras Cardiol. 2005; 84(1):3-28

13. Craig CL, Marshall AL, Sjöström M, Bauman AE, Booth ML, Ainsworth BE, et al. International physical activity questionnaire: 12 -country reliability and validity. Med Sci Sports Exerc. 2003; 35(8):1381-95.

14. Sjostrom M, Ainsworth B, Bauman A, Bull F, Craig C, Sallis J. Guidelines for Data Processing and Analysis of the International Physical Activity Questionnaire (IPAQ) - Short and Long Forms. [cited 2010 Jun 8]. Available from: http://www.ipaq.ki.se/scoring.pdf/.

15. Fornés NS, Stinguini MAF. Development of a food frequency questionnaire (FFQ) and characterization of the food pattern consumption for lowincome workers in the city of Goiânia, Goiás State, Brazil. Acta Sci Health Sci. 2005; 27(1):69-75.

16. Massari M, Freeman KM, Seccareccia F, Menotti A, Farchi G; Research Group of the RIFLE Project. An index to measure the association between dietary patterns and coronary heart disease risk factors: findings from two Italian studies. Prev Med. 2004; 39(4):841-7.

17. Crum-Cianflone N, Tejidor R, Medina S, Barahona I, Ganesan A. Obesity among HIV patients: the latest epidemic. AIDS Patient Care STDS. 2008; 22(12):925-30.

18. Kroll AFK, Sprinz E, Leal SC, Labrêa MC, Setúbal S. Prevalence of obesity and cardiovascular risk in patients with HIV/AIDS in Porto Alegre, Brazil. Arq Bras Endocrinol Metab. 2012; 56(2):137-41.

19. Silva EFR, Lewi DS, Vedovato GM, Garcia VRS, Tenore SB, Bassichetto KC. Estado nutricional, clínico e padrão alimentar de pessoas vivendo com HIV/ aids em assistência ambulatorial no município de São Paulo. Rev Bras Epidemiol. 2010; 13(4):677-88.

20. Instituto Brasileiro de Geografia e Estatística. Pesquisa de Orçamentos Familiares 2008-2009. Antropometria e estado nutricional de crianças, adolescentes e adultos no Brasil. Rio de Janeiro: IBGE, 2010

21. Shah K, Alio AP, Hall WJ, Luque AE. The physiological effects of obesity in HIV-infected patients. J AIDS Clinic Res. 2012; 3(4):2-6.

22. Greene M, Justice AC, Lampiris HW, Valcour V. Management of human immunodeficiency virus infection in advanced age. JAMA. 2013; 309(13):1397405.

23. Hejazi N, Lee MHS, Lin KG, Choong CLK. Factors associated with abdominal obesity among HIV-infected adults on antiretroviral therapy in Malaysia. GJHS. 2010; 2(2):20-31.

24. Cahn P, Leite O, Rosales A, Cabello R, Alvarez CA, Seas CR, et al. Metabolic profile and cardiovascular risk factors among Latin American HIV-infected patients receiving HAART. Braz J Infect Dis. 2010; 14(2):158-66.

25. Diehl LA, Dias JR, Paes AC, Thomazini MC, Garcia LR, Cinagawa E, et al. Prevalência da lipodistrofia associada ao HIV em pacientes ambulatoriais brasileiros: relação com síndrome metabólica e fatores de risco cardiovascular. Arq Bras Endocrinol Metabol. 2008; 52(4):658-67.

26. Jaime PC, Florindo AA, Latorre MRDO, Segurado AAC. Central obesity and dietary intake in HIV/AIDS patients. Rev Saúde Pública. 2006; 40(4):634-40.

27. Holanda LGM, Martins MCC, Souza Filho MD, Carvalho CMRG, Assis RC, Leal LMM, et al. Excesso de peso e adiposidade central em adultos de TeresinaPI. Rev Assoc Med Bras. 2011; 57(1):50-55

28. Gigante DP, Moura EC, Sardinha LMV. Prevalência de excesso de peso e obesidade e fatores associados, Brasil, 2006. Rev Saúde Pública. 2009; 43(Suppl 2):83-9.

29. Leite LHM, Sampaio ABMM. Progression to overweight, obesity and associated factors after antiretroviral therapy initiation among Brazilian persons with HIV/AIDS. Nut Hosp. 2010; 25(4):635-40

30. Grinspoon S, Carr A. Cardiovascular risk and body-fat abnormalities in HIV-infected adults. N Engl J Med. 2005; 352(1):48-62.

31. Koethe JR, Jenkins CA, Shepherd BE, Stinnette SE, Sterling TR. An optimal body mass index range associated with improved immune reconstitution among HIV-infected adults initiating antiretroviral therapy. Clin Infect Dis. 2011; 53(9):952-60.

32. Johnson K, Cai B, Duffus W, White K, Smieja M, Divya A, et al. Longitudinal association between BMI at diagnosis and HIV disease progression. AIDS Behav. 2014; 18(11):2249-57.

33. Crum-Cianflone N, Roediger M, Eberly LE, Vyas K, Landrun ML, Ganesan A, et al.; nfectious Disease Clinical Research Program HIV Working Group. Obesity among HIV-Infected persons: impact of weight on CD4 cell count. AIDS. 2010; 24(7):1069-72.

34. Rocha PB, Schuch I. Perfil alimentar e nutricional dos pacientes HIV positivo atendidos em um serviço público de saúde de Porto Alegre/RS. J Brazilian Soc Food Nutr. 2009; 34(3):1-15. 